\title{
Development of Learning Media for Automotive Charging System Based on Macromedia Flash Vocational School
}

\author{
Suyitno Suyitno ${ }^{1, *}$, Riawan Yudi Purwoko ${ }^{1}$, Yuli Widiyono ${ }^{1}$, Dwi Jatmoko ${ }^{1}$, M. Nurtanto ${ }^{2}$, \\ Zainudin Hassan ${ }^{3}$ \\ ${ }^{1}$ Faculty of Teacher Training and Education, Universitas Muhammadiyah Purworejo, Indonesia \\ ${ }^{2}$ Faculty of Teacher Training and Education, Universitas Sultan Ageng Tirtayasa, Indonesia \\ ${ }^{3}$ Faculty of Social Science and Humanities, Universiti Teknologi Malaysia (UTM), Malaysia
}

Received June 24, 2020; Revised October 1, 2020; Accepted November 7, 2020

\section{Cite This Paper in the following Citation Styles}

(a): [1] Suyitno Suyitno, Riawan Yudi Purwoko, Yuli Widiyono, Dwi Jatmoko, M. Nurtanto, Zainudin Hassan, "Development of Learning Media for Automotive Charging System Based on Macromedia Flash Vocational School," Universal Journal of Educational Research, Vol. 8, No. 11C, pp. 64 - 71, 2020. DOI: 10.13189/ujer.2020.082308.

(b): Suyitno Suyitno, Riawan Yudi Purwoko, Yuli Widiyono, Dwi Jatmoko, M. Nurtanto, Zainudin Hassan (2020). Development of Learning Media for Automotive Charging System Based on Macromedia Flash Vocational School. Universal Journal of Educational Research, 8(11C), 64 - 71. DOI: 10.13189/ujer.2020.082308.

Copyright $\bigcirc 2020$ by authors, all rights reserved. Authors agree that this article remains permanently open access under the terms of the Creative Commons Attribution License 4.0 International License

\begin{abstract}
This study aims to: (1) determine the feasibility of learning media for electric charging systems based on Macromedia Flash 8 and (2) to determine the ratio of student learning outcomes of the learning medium electrical charging system based on Macromedia Flash 8. This research's method is the Research and Development (R \& D) based on the 4D research and development model. Steps being taken, namely the definition phase (define), the planning (design), stage of development (develop), and the deployment phase (disseminate). Data collection techniques in this study were interviews, observation, and questionnaires. The object of research is the vocational school. Based on the results of the validation by the material, experts obtained an average score of cumulative learning media by $90,0 \%$ with the criteria "Very Eligible". There is no revision of the material. The average incremental score validation by media experts by $90,0 \%$ with standards" Very Decent, the trial is conducted through 2 stages, namely the control class trial and experimental class trial. Before being tested on the control and experimental classes, small group and large group tests were performed. In the small group trials, an average score of $93,7 \%$ was obtained with the criteria "Valid," and the extensive group trial results obtained an average score of $94.8 \%$ with the criteria "Valid." Test try experimental class earned an average score of 86,7 with the requirements of
\end{abstract}

"Good" means that the media developed feasible to use and ready to be used as teaching materials.

Keywords Charging System, Media Learning, Macromedia Flash 8, Vocational School

\section{Background/ Objectives and Goals}

Learning is essential and fundamental for every individual because education is a process of transfer of knowledge from educators to students [1]. The role of educators is providing information and pouring learning materials as much as possible to the learners. Learning is fundamental in human life; by learning, humans make individual qualitative changes so that their behavior develops. Learning is a complex process in every person throughout his life [2], [3]. The learning process occurs because of the interaction between a person and his environment [4]. Learning is an activity, both physical and psychological, which results in new behavioral changes in individuals who learn in the form of relatively constant abilities and not caused by maturity or something temporary.

The results of learning activities are characterized by 
changes in behavior in a relatively permanent positive direction in people who learn [5]. A person can be said to have succeeded in learning to show a change in him [6]. Student learned as a result of positive changes in behavior, mindset, outlook, and students' ability from an interaction act of teaching and learning in learning outcomes of intellectual, cognitive strategies, attitudes and values, innovation, verbal and motor learning products. These changes can be interpreted as an increase and development that is better than before.

Vocational education learning cannot be separated from the media [7]. Media is a means of channeling messages or learning information that would be submitted by the source of the message to the target or recipient of the message [8] [9]. The use of instructional media can help achieve successful learning [10-12, 27]. Nowadays, there are many assisted by the learning media with Macromedia Flash. Macromedia Flash is a software application for animation that can be used for the Web. With Macromedia Flash, we can equip a website with several kinds of animations, sounds, interactive animations, and others. The technology has emerged vary drastically, and the learning process in today's environment goes beyond the expectation in this competitive world [13]. In the modern era, teachers must be able to create learning media that attract students [14]. Macromedia Flash 8 is a software that is modern and can be used to add dynamic aspects of Web or interactive animated film. Software Macromedia Flash 8 is an application which can make learning media in the form of text, images, and animations, which then between each function is the function of writing, the function of drawing and animation function can be incorporated into media that have utility more than one function and with their Macromedia Flash 8 application is expected for educators to be more creative in improving learning so as to improve student learning outcomes.

From the results of observations and interviews conducted, it was also found that the student scores of several vocational education subjects, especially the filling system, were still low. In the Covid 19 era, there were still most teachers who used the lecture method and also used a blackboard during the learning process. In fact, vocational education aims to prepare students for work [15] - [17]. Another factor that causes low student learning outcomes is because teachers have not optimally utilized media such as audio-video or other media such as animation and the like. Learning outcomes can be seen from the value of the Mid-Semester Assessment, and this can also be seen from the attitudes of students following the learning process.

Based on these considerations, the researchers tried to develop a media charging system based on Macromedia Flash 8 as a learning medium. It is hoped that this learning media can attract students to learn the electrical charging system material so that competency standards can be achieved through the learning process by following the instructions given by the teacher.

\section{Methods}

This research is a type of Research and Development (R\&D). The research and development used in this study is the 4D model short for Define, Design, Development and Dissemination [18]. Research and development are research methods used to produce certain products and test the effectiveness of these products [19], [20] . To be able to produce certain products, used research that is needs analysis and to test the effectiveness of these products in order to function in the wider community.

\section{The definition phase (Define )}

This define phase includes four main steps, namely front-end analysis, front-end analysis, concept analysis, task analysis, and formulation of learning objectives (specifying instructional objectives).

\section{Stage Design (Design)}

In this design, the phase aims to design teaching materials for learning tools to obtain initial concepts. a) Selection of Teaching Materials: the chosen teaching material is the charging system animation teaching material which aims to facilitate the learning process because animation-based teaching material is very relevant and easily liked by students at this time, b) Selection Format (Format Selection): the choice of format in the development of learning tools is intended to design or design the contents of learning materials, c) Initial Design: based on the analysis that has been obtained, the design of learning tools is accepted, namely teaching materials that must be worked out before being tested by experts.

\section{Development Phase (Develop)}

The goal at this stage is to produce teaching materials for the electrical charging system animation. The activities carried out at this stage the researchers validated teaching materials in the form of an animation charging system on the car to the material expert and the media expert, after which they tested the student responses.

\section{4. $\quad$ Spread Phase (Dessiminate)}

The disseminate stage is the final stage of development. Dissemination step was done to promote product development so that it can be accepted by users, both individual, group or system. At this stage, deployment is done by way of disseminating learning media products to the schools studied. Design validation is a process of activities to assess whether the product design, in this case, the new work system will rationally be more effective than the old one or not. It is said rationally because the validation here is still an evaluation based on rational thought, not field facts. In this research, the proof is in the form of product design validation.

Data analysis is an activity after the data from all respondents, or other data sources are collected. Activities in data analysis are grouping data based on variables and 
types of respondents, tabulating data based on variables from all respondents, presenting data from each variable, doing calculations to answer the problem formulation. The technique used to analyze qualitative and quantitative data, then the data were analyzed by descriptive statistics. According to Sugiyono (2015: 207), descriptive statistics are statistics that function to describe or provide an overview of the object under study through data samples or existing populations.

a. Mean or average value.

b. Median or middle value.

c. Mode or data values that often appear.

$\mathrm{T}$ test is used to compare the average learning outcomes of the experimental group and the control group [22] . Table 1 is used to see product eligibility. If the product is valid with a score of $80-100,60-79$ is quite valid, less than
50 is not valid.

Table 1. Criteria for Interpretation of Scores Based on Intervals [21]

\begin{tabular}{|c|c|}
\hline Final Score & Classification \\
\hline $80-100 \%$ & Valid \\
\hline $60-79$ & Valid enough \\
\hline $50-59$ & Invalid \\
\hline$<50$ & Invalid \\
\hline
\end{tabular}

\section{Results}

From the results of research on the development of learning media for charging systems based on Macromedia Flash 8, the following results are obtained:

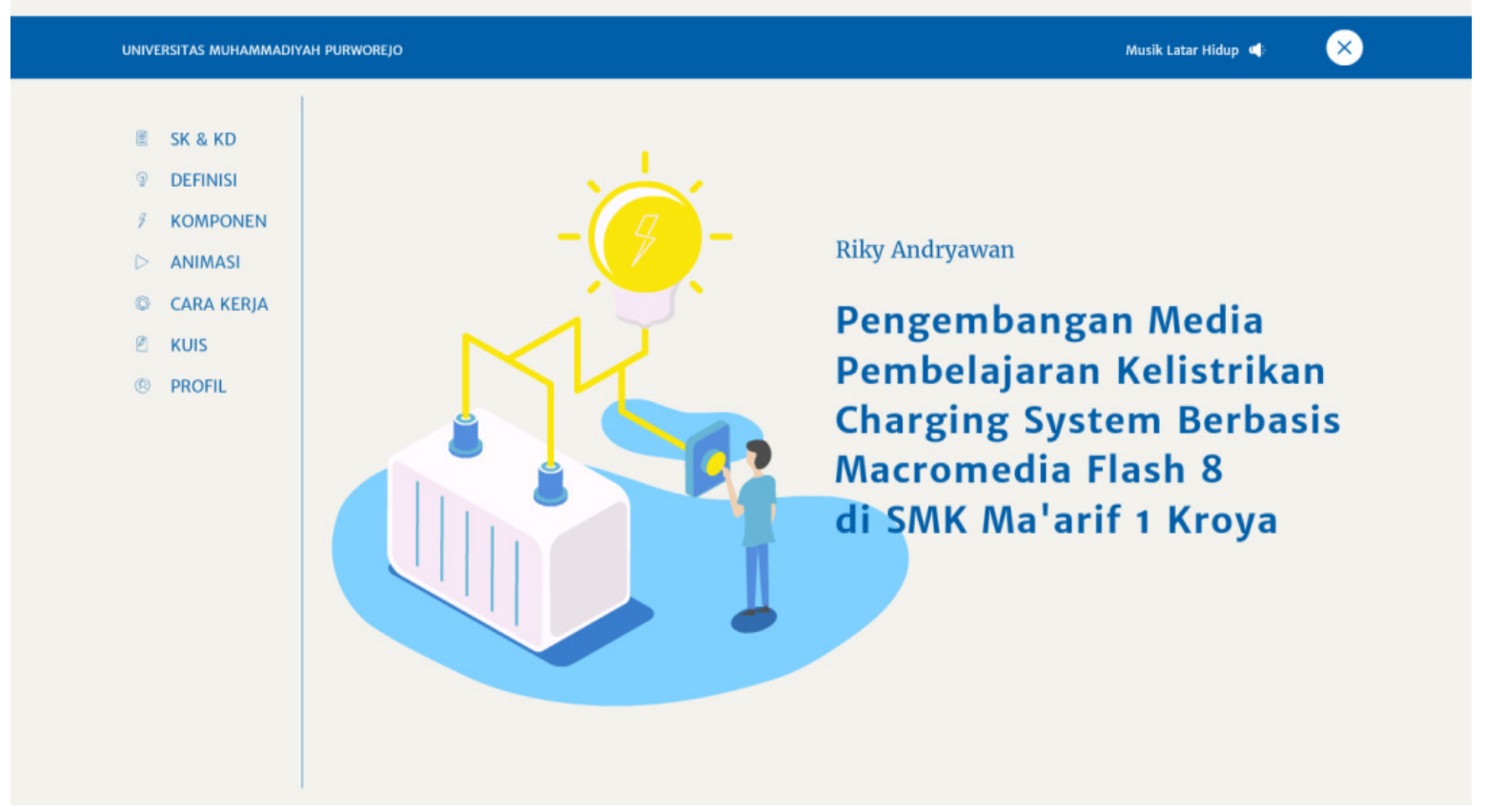

Figure 1. Display of learning media titles and menus

From Figure 1 above is a display of the learning media title. From this title, there are menus provided to make it easier to link to the next menu. From the menu contains competency standards, definitions, components, animation, work methods, quizzes and learning media profiles. 


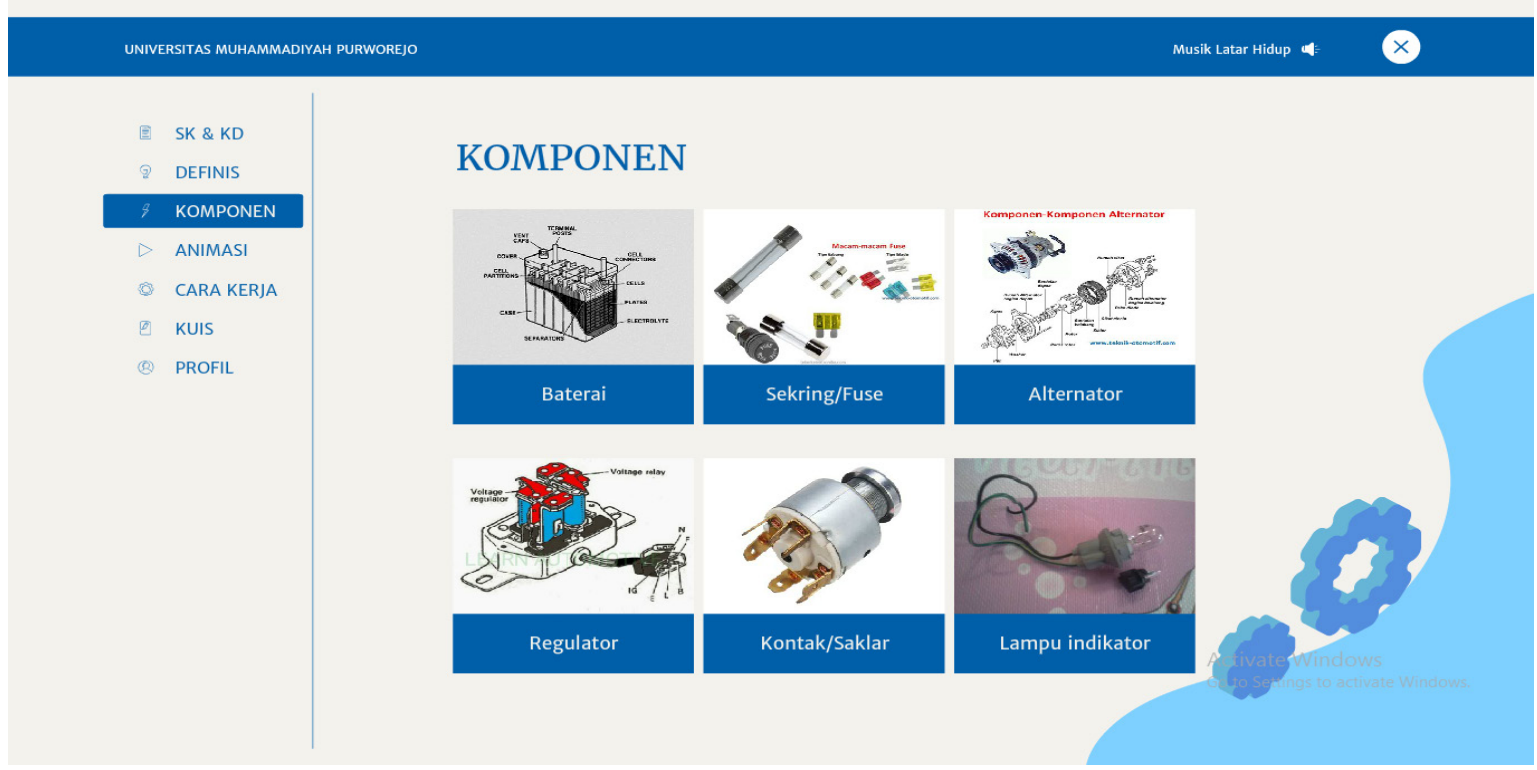

Figure 2. Menu display and learning media components

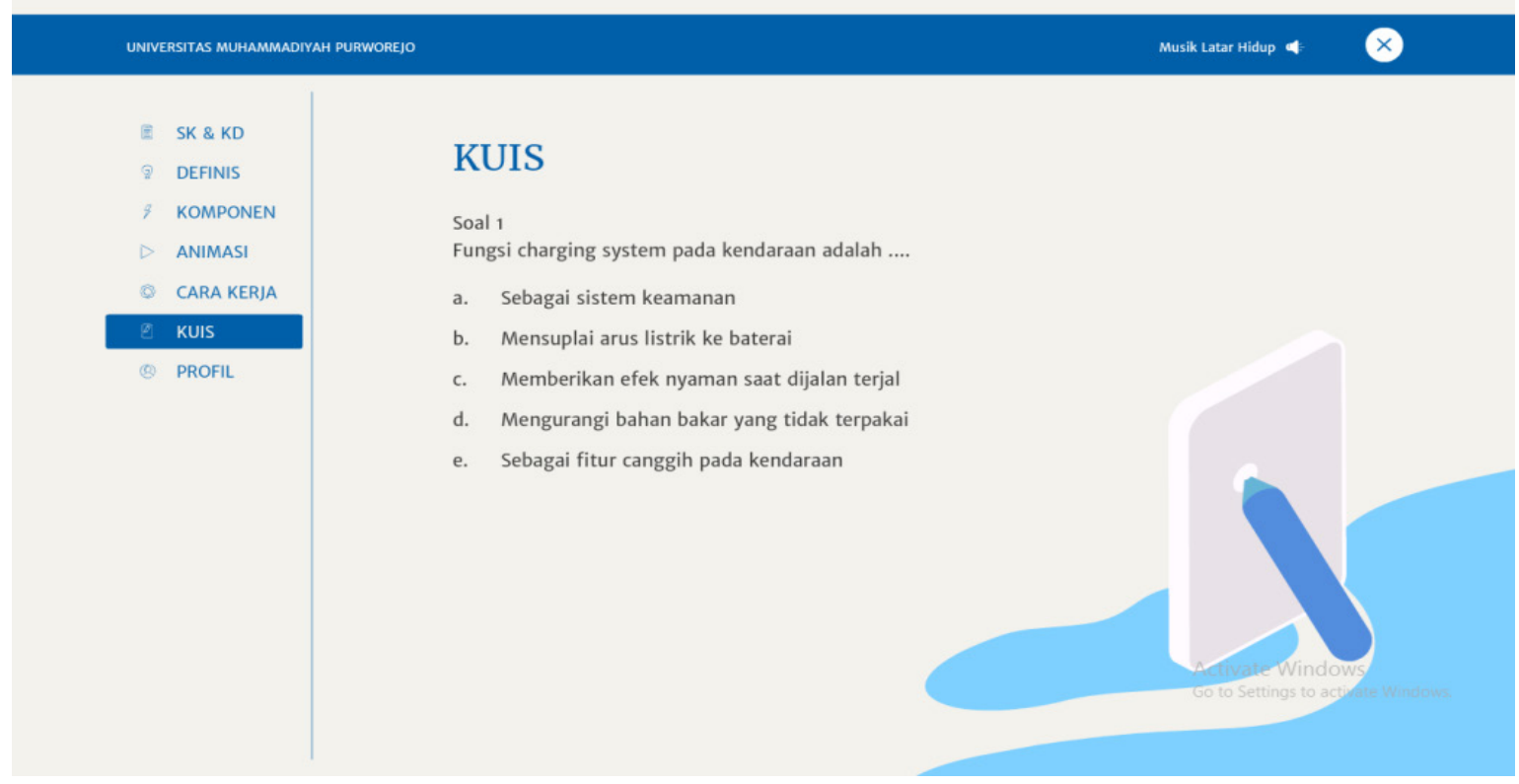

Figure 3. Menu display and learning quizzes

In Figure 2 about the menu display and the components of learning media, it can be seen that in this learning media there are pictures and animations to make it easier to learn the material given.

Based on Figure 3, there is a quiz menu that is used by students to practice questions. Students can practice questions independently with this learning media. Macromedia flash learning media display contains the title of competence, learning objectives, the name of the filling system components, component functions, animation of how to work, and the existence of exam questions by students. 
Table 2. Results of Expert Data Validation Results

\begin{tabular}{|c|c|c|c|c|}
\hline No & Item Questions & Score & (\%) & OPTION \\
\hline 1 & Media is relevant to the material students must learn & 4 & 100 & A \\
\hline 2 & $\begin{array}{c}\text { The design of instructional media is in accordance with the rules of learning provisions } \\
\text { to be presented }\end{array}$ & 3 & 79 & B \\
\hline 3 & Learning objectives are clearly stated & 4 & 100 & A \\
\hline 4 & This medium can facilitate students in mastering the material & 4 & 100 & A \\
\hline 5 & The medium does not interfere with student concentration & 3 & 79 & B \\
\hline 6 & The duration used is simple and clear & 4 & 100 & A \\
\hline 7 & The material presented is concise and clear & 3 & 79 & B \\
\hline 8 & Each slide has the right explanation & 3 & 79 & B \\
\hline 9 & Fill in the material in accordance with Basic Competence & 4 & 100 & A \\
\hline 10 & Media deserve to be tested in research & 4 & 100 & A \\
\hline & Number of Scores obtained & R) & 36 \\
\hline & Total Score Total & $(\mathrm{BC})$ & & 40 \\
\hline
\end{tabular}

Table 3. Validation Data by Media Experts

\begin{tabular}{|c|c|c|c|c|}
\hline No & Item Questions & Score & (\%) & OPTION \\
\hline 1 & The animation presented is suitable to be released as an interactive learning media & 4 & 100 & A \\
\hline 2 & The design of interactive learning media is in accordance with the rules of learning \\
provisions to be presented & 3 & 79 & B \\
\hline 3 & The sound in the animation matches the tempo of the description on the video & 4 & 100 & A \\
\hline 4 & The language used is easy to understand & 4 & 100 & A \\
\hline 5 & The writing on each page is not dense & 3 & 79 & B \\
\hline 6 & Sound and resolution are correct & 4 & 100 & A \\
\hline 7 & The font size reading used is complete & 3 & 79 & B \\
\hline 8 & The language used is consistent and easy to understand & 4 & 100 & A \\
\hline 9 & The material presented is in accordance with the research title & 3 & 79 & B \\
\hline 10 & Animation and video are in accordance with the research title & 4 & 100 & A \\
\hline & Number of Scores obtained & R) & 36 \\
\hline & Total Score Total & $(\mathrm{BC})$ & & 40 \\
\hline & Percentage Value & & 90 \\
\hline
\end{tabular}

Based on table 2, it can be seen that there are 6 question items that get an A. Based on the data from the table 2 then analyzed with a statistical formula to obtain the percentage, namely : Based on the data validation criteria, a percentage of $90 \%$ is included in the valid criteria. It can be concluded that the learning media of electricity charging system based on Macromedia Flash 8 developed is feasible to be used to the next stage.

Based on table 3, it can be seen that from the media experts stated that there were 6 questions that got an A, and 4 got a B. Based on the results of validation by the validator consisting of 10 instruments with aspects of the design quality of learning media charging systems based on Macromedia Flash 8, the contents of the material and the benefits of teaching media get figures with an average percentage of $90 \%$ with the criteria " Very Good / Very Eligible."
Based on the data from the table 3, then analyzed with a statistical formula to obtain the percentage, namely: Based on data validation criteria with a rate of $90 \%$ included in the valid criteria. So it was concluded that the material developed in the form of learning media based on Macromedia Flash 8 is feasible to use to the next stage.

\section{Small Group Trial Data}

Based on the results of the validation of the learning media, electrical charging system based on Macromedia Flash 8 developed by researchers declared valid and feasible to be used in small group trials. This small group trial was conducted in a class of 30 students. The recapitulation of the small group trial response questionnaire is as follows : 
Table 4. Recapitulation of Small Group Test Results

\begin{tabular}{|c|c|c|c|c|c|c|}
\hline No & Statement & A & B & C & D & $\begin{array}{c}\text { Average value } \\
(\%)\end{array}$ \\
\hline 1 & The material presented is clear and easy to understand & 22 & 8 & - & - & $94.4 \%$ \\
\hline 2 & The material presented is clearly brief and clear & 20 & 8 & 2 & - & $91.6 \%$ \\
\hline 3 & Get new experiences from learning media & 25 & 5 & - & - & $96.5 \%$ \\
\hline 4 & The language conveyed is easy to understand and clear intonation & 15 & 14 & 1 & - & $88.8 \%$ \\
\hline 5 & The media can make it easier to memorize / remember material & 22 & 8 & - & - & $94.4 \%$ \\
\hline 6 & The material presented can be repeated again & 22 & 6 & 2 & - & $93 \%$ \\
\hline 7 & The tempo of the material can be adjusted as desired & 17 & 10 & 3 & - & $88.9 \%$ \\
\hline 8 & The video presented in the animation is easy to understand & 25 & 5 & - & - & $96.5 \%$ \\
\hline 9 & Interest in learning to use Macromedia Flash 8 learning media & 27 & 2 & 1 & - & $97.2 \%$ \\
\hline 10 & The writing in the media is clear and easy to read & 25 & 4 & 1 & - & $95.8 \%$ \\
\hline \multicolumn{2}{|c|}{ Total } & 220 & 70 & 10 & 0 & $937 \%$ \\
\hline & Average & 22 & 7 & 1.6 & $93.7 \%$ \\
\hline
\end{tabular}

Table 5. Recapitulation of Large Group Test Results

\begin{tabular}{|c|c|c|c|c|c|c|}
\hline No & Statement & A & B & C & D & $\begin{array}{c}\text { Average } \\
\text { value (\%) }\end{array}$ \\
\hline 1 & The material presented is clear and easy to understand & 22 & 3 & - & - & $97.48 \%$ \\
\hline 2 & The material presented is clearly brief and clear & 20 & 3 & 2 & - & $94.5 \%$ \\
\hline 3 & Get new experiences from learning media & 18 & 5 & 2 & - & $92.5 \%$ \\
\hline 4 & The language conveyed is easy to understand and clear intonation & 18 & 7 & - & - & $94 \%$ \\
\hline 5 & The media can make it easier to memorize / remember material & 17 & 8 & - & - & $93.2 \%$ \\
\hline 6 & The material presented can be repeated again & 20 & 3 & 2 & - & $97 \%$ \\
\hline 7 & The tempo of the material can be adjusted as desired & 17 & 5 & 3 & - & $90.8 \%$ \\
\hline 8 & The video presented in the animation is easy to understand & 25 & - & - & - & $100 \%$ \\
\hline 9 & Interest in learning to use Macromedia Flash 8 learning media & 22 & 2 & 1 & - & $96.6 \%$ \\
\hline 10 & The writing in the media is clear and easy to read & 21 & 4 & - & - & $92.6 \%$ \\
\hline & Total & 200 & 40 & 10 & - & $948.68 \%$ \\
\hline & Average & 20 & 4 & 1 & - & $94.8 \%$ \\
\hline
\end{tabular}

Based on table 4, there are 10 items of small scale trial test recapitulation. Based on the analysis of the data above, it is known that the datum from small group trials is $93.7 \%$. Based on the predetermined data interpretation criteria, that $93.7 \%$ are included in the valid criteria so it is concluded that the learning media of the charging system based on Macromedia Flash 8 and enter into the valid criteria and can be used in the next stage of the final product implementation.

\section{Final Product Implementation Data}

The final product implementation is carried out to see whether the media developed by this researcher are effective and efficient for use in the learning process for students. Implementation of the final product in this study was carried out by involving 25 students. To see a more detailed recapitulation of the questionnaire, responses in large group trials or the final product implementation can be seen in the table 5 .

Based on table 5, there are 10 item questions for large-scale test trials. The results of trials related to the feasibility of electrical learning media charging system based on Macromedia Flash 8 are carried out through two stages, namely the control class test and the experimental class test conducted in the experimental class, namely class XII with 41 students and class XII TKR 3 with number of students 43 . Also the comparison of graph charts between the control class and the experimental class is as follows: 


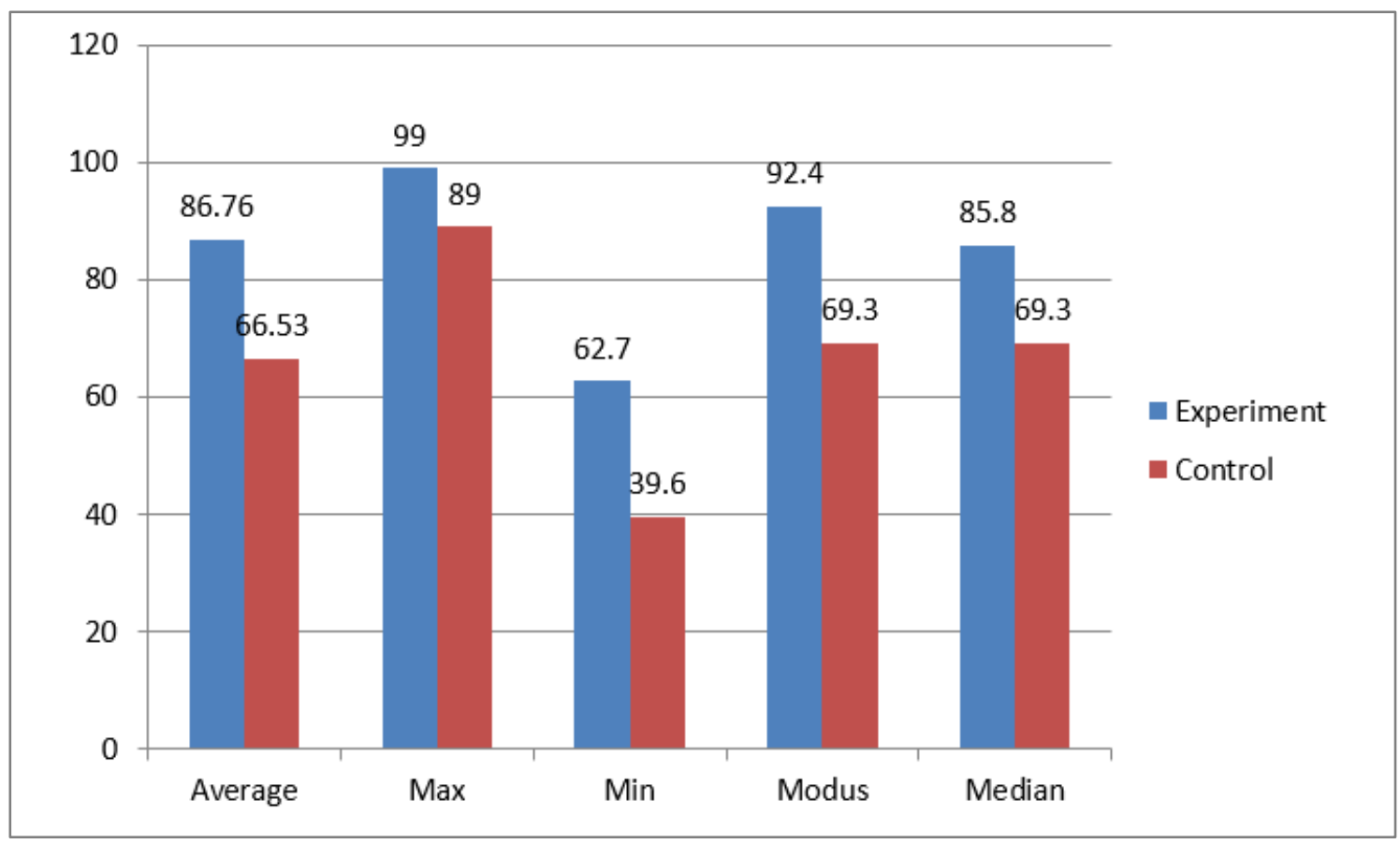

Figure 4. Comparison of Control Class Test Results with Experiment Classes

Based on Figure 4, it can be explained about the differences in the mean, maximum, minimum, mode and median values between the experimental class and the control class. In the control class, test dipe $r$ by the average value 66.5 with the criteria of "Not Eligible" and the experimental class test gained an average value of 86.7 criteria "Eligible". This medium has a high level of ease of understanding video. Video has a high level of motivation $[23-26,28]$. Thus the developed media can facilitate students to be able to carry out the learning process in accordance with the modern era.

\section{Conclusions}

From the results of this research and development, it can be concluded as follows: 1) The feasibility of learning media charging system based on Macromedia Flash 8 based system is known that the results of validation by material experts get a percentage value of $90 \%$ with the criteria "Very Good," then from the expert, the material does not suggest improvements, and states that learning media is appropriate to be used without revision, while validation by media experts is $90 \%$ with the criteria of "Very Good.", 2 ) The results of field trials showed an increase in learning outcomes of the charging system electrical material after being given a charging system based on Macromedia Flash 8 as a control class and class XII TKR 1 as an experimental class, namely by comparison of the control class with an average value of 66,53 , and the experimental class with an average value of 86.76 . Thus the comparison of the control class and the experimental class given the material charging system is based on
Macromedia Flash 8 an increase in the value of 20.23 or a percentage of $20.23 \%$. Thus the results of field trials on the learning media developed have increased so that the learning media are said to be feasible, or this research has succeeded.

\section{Acknowledgements}

We would like to thank the Teacher Training and Education Faculties, Universitas Muhammadiyah Purworejo, Indonesia to support this study. Also, we like to thank the institution of TAST for release the data for this study to analyze in order to get the result.

\section{REFERENCES}

[1] N. I. Naumkin, N. N. Shekshaeva, S. I. Kvitko, M. V. Lomatkina, V. F. Kupryashkin, dan I. V. Korovina, "Designing the Teaching Model of Multilevel Gradual Training of Students in Innovative Engineering," Integr. Educ., vol. 23, no. 4, hlm. 568-586, Des 2019, doi: 10.15507/1991-9468.097.023.201904.568-586.

[2] P. Sakulviriyakitkul, K. Sintanakul, dan J. Srisomphan, "The Design of a Learning Process for Promoting Teamwork using Project-Based Learning and the Concept of Agile Software Development," Int. J. Emerg. Technol. Learn. IJET, vol. 15, no. 03, hlm. 207, Feb 2020, doi: 10.3991/ijet.v15i03.10480.

[3] I. W. Santyasa, Universitas Pendidikan Ganesha, Indonesia, I. W. W. Sara, dan Universitas Pendidikan Ganesha, 
Indonesia, "Project Based Learning and Academic Procrastination of Students in Learning Physics," Int. J. Instr., vol. 13, no. 1, hlm. 489-508, Jan 2020, doi: 10.29333/iji.2020.13132a.

[4] P. Jaiswal, "Integrating Educational Technologies to Augment Learners' Academic Achievements," Int. J. Emerg. Technol. Learn. IJET, vol. 15, no. 02, hlm. 145, Jan 2020, doi: 10.3991/ijet.v15i02.11809.

[5] T. Rokhmani, B. Sujanto, dan M. R. Luddin, "The Implementation of Academic Responsibility in Higher Education: A Case Study," Integr. Educ., vol. 23, no. 3, hlm. 336-349, Sep 2019, doi: 10.15507/1991-9468.096.023.201 903.336-349.

[6] R. O. Agavelyan, S. D. Aubakirova, A. D. Zhomartova, dan E. I. Burdina, "Teachers' Attitudes towards Inclusive Education in Kazakhstan," Integr. Educ., vol. 24, no. 1, hlm. 8-19, Mar 2020, doi:10.15507/1991-9468.098.024.202001. 008-019.

[7] R. A. Nabawi dan F. Prasetya, "Media Development of Mechanical Drawing Course Based on Project-Based Learning," Int. J. Innov. Creat. Change, vol. 11, no. 4, hlm. 309-319, 2020.

[8] S. Suyitno, J. Dwi, S. Arif, dan P. Aci, "Trainer Stand Instructional Media of Wiring System for Kijang Car to Improve Student Achievement in Vocational Higher Education," Jour Adv Res. Dyn. Control Syst., vol. 11, no. 11, hlm. 991-997, 2019, doi: 10.5373/JARDCS/V11SP11/2019 3126 .

[9] N. Yue, "Computer Multimedia Assisted English Vocabulary Teaching Courseware," Int. J. Emerg. Technol. Learn. IJET, vol. 12, no. 12, hlm. 67, Des 2017, doi: 10.3991/ijet.v12i12.7955.

[10] Z. K. Avery dan E. M. Reeve, "Developing Effective STEM Professional Development Programs," J. Technol. Educ., vol. 25, no. 1, hlm. 1-15, Sep 2013, doi: 10.21061/jte.v25i1.a.4.

[11] Y. Zheng, "Inquiry Based Teaching in an Animation Multimedia Course," Int. J. Emerg. Technol. Learn. IJET, vol. 14, no. 17, hlm. 17, Sep 2019, doi: 10.3991/ijet.v14i17.11387.

[12] S. Suyitno, I. Widianto, dan S. binti Masrul, "Development of Learning Media for the Course of Two-Stroke Gasoline Motors to Improve Students' Learning Outcomes," $J$. Pendidik. Teknol. Dan Kejuru., vol. 24, no. 1, hlm. 83-90, 2018.

[13] V. Karthikayini, "Virtual Reality Classrooms for Today's Generation 'IGEN,", Int. J. Adv. Sci. Technol., vol. 29, no. 3, hlm. 6, 2020 .

[14] R. M. Tawafak, A. AlSideir, G. Alfarsi, M. N. Al, S. I. Malik, dan J. Jabbar, "E-learning Vs. Traditional Learning for Learners Satisfaction," Int. J. Adv. Sci. Technol., vol. 29, no. 3, hlm. 10, 2020.

[15] K. Komariah, H. Sofyan, dan T. Mahfud, "Work-based Learning Model and Its Urgency in Preparing Culinary Art Education Graduates," Int. J. Adv. Sci. Technol., vol. 29, no. 3, hlm. 10, 2020.
[16] [16] S. Suyitno dan P. Pardjono, "Integrated work-based learning (I-WBL) model development in light vehicle engineering competency of vocational high school," $J$. Pendidik. Vokasi, vol. 8, no. 1, hlm. 1, Feb 2018, doi: 10.21831/jpv.v8i1.14360.

[17] M. Nurtanto, H. Sofyan, P. Pardjono, dan S. Suyitno, "Development model for competency improvement and national vocational qualification support frames in automotive technology," Int. J. Eval. Res. Educ. IJERE, vol. 9, no. 1, 2020, doi: https://doi.org/10.11591/ijere.v9i1.2044 7.

[18] R. Mayefis dan S. Barat, "Development of Android Based Mobile Learning Media on Computer Assembly at a Vocational High School," Int. J. Innov. Creat. Change, vol. 11, no. 4, hlm. 347-361, 2020.

[19] S. Sugiyono, Metode Penelitian Kuantitatif, Kualitatif, Dan $R \& D$. Bandung: Alfabeta, 2015

[20] S. Suyitno, Metodologi Penelitian Tindakan Kelas, Eksperimen, dan $R \&$ D. Alfabeta, 2018.

[21] S. Arikunto dan C. Safruddin A.J, Evaluasi Program Pendidikan, 1 ed. Jakarta: Bumi Aksara, 2009.

[22] K. G. Joreskog dan D. Sorbom, Structural Equation Modelling with The Simplis Command Language, 1 ed. USA: Scientific Sofware International, Inc., 1993.

[23] S. Muthurman, R. Veerasamy, dan M. Al, "E-Learning to Enhance Educational Competitiveness in the Sultanate of Oman," Int. J. Innov., vol. 11, no. 2, hlm. 84-92, 2020.

[24] M. Rifai, S. Masitoh, B. S. Bachri, W. H. Setyawan, N. Nurdyansyah, dan H. Puspitasari, "Using Electronic Design Automation and Guided Inquiry Learning Model in Higher Engineering Education," Univers. J. Educ. Res., vol. 8, no. 7, hlm. 2946-2953, Jul 2020, doi: 10.13189/ujer.2020.080723.

[25] K. Basriyah, D. Sulisworo, G. Maruto, M. Toifur, dan N. H. A. Rahman, "Effects of the Flipped Classroom on Understanding the Thermodynamic Concept at High School Students," Univers. J. Educ. Res., vol. 8, no. 3B, hlm. 51-58, Mar 2020, doi: 10.13189/ujer.2020.081506.

[26] I. Mubarak, W. Warju, F. D. Isnantyo, M. Nurtanto, dan S. Suyitno, "Enhancing the Learning Outcomes of Automotive Electrical Wiring Diagram through Android Simulation - A Conceptual Design for Automotive Vocational School," Int. J. Psychosoc. Rehabil., vol. 24, no. 08, hlm. 10694-10705, 2020, doi: 10.37200/IJPR/V24I8/PR281066.

[27] Riski Astuti Liliana, Widodo Raharjo, Ishafit Jauhari, Dwi Sulisworo (2020). Effects of the Online Interactive Learning Media on Student's Achievement and Interest in Physics. Universal Journal of Educational Research, 8(3B), 59 - 68. DOI: 10.13189/ujer.2020.081507.

[28] Khusnul Basriyah, Dwi Sulisworo, Guntur Maruto, Moh Toifur, Nurul Huda Abd Rahman (2020). Effects of the Flipped Classroom on Understanding the Thermodynamic Concept at High School Students. Universal Journal of Educational Research, 8 (3B), 51 - 58. DOI: 10.13189/ujer.2020.081506. 